\title{
FORMULATION OF THE SERUM GEL CONTAINING GREEN COFFEE BEAN (Coffea robusta L) EXTRACT AS AN ANTIOXIDANT AND TYROSINASE ENZYME INHIBITOR
}

\author{
D. L. Aulifa ${ }^{1, *}$, M. Caroline ${ }^{1}$, D. Tristiyanti ${ }^{2}$ and A. Budiman ${ }^{3}$ \\ ${ }^{1}$ Department of Pharmaceutical Biology, Indonesia School of Pharmacy, Bandung-40266, \\ West Java, Indonesia \\ ${ }^{2}$ Department of Pharmaceutics, Indonesia School of Pharmacy, Bandung-40266, \\ West Java, Indonesia \\ ${ }^{3}$ Department of Pharmaceutics and Pharmaceutical Technology, Faculty of Pharmacy, \\ Universitas Padjadjaran, Sumedang-45363, West Java, Indonesia \\ *E-mail: diahliaaulifa@stfi.ac.id
}

\begin{abstract}
People who expose to the sun might develop hyperpigmentation or skin spots. Hyperpigmentation is caused by an enzymatic reaction such as tyrosinase and could be reduced by using a sunscreen product. Many studies reported that coffee has antioxidant activity, especially green coffee. Its natural sources such as caffeine, chlorogenic acids, and phenolic compounds are known as potential antioxidants. This research, therefore, aims to formulate and evaluate green coffee bean (Coffea robusta L) extract in serum gel as antioxidants and tyrosinase enzyme inhibitors. The phenolic total of the green coffee bean (GCB) was conducted by Folin-Ciocalteu assay. The antioxidant activity was determined using the 1,1-diphenyl-2-picrylhydrazyl (DPPH) assay, and tyrosinase enzyme L-Tyrosine as substrate. The GCB extract and kojic acid were formulated into serum gel dosage form and evaluated for physical stability. The result showed that the total phenol of GCB extract was $9.51 \mathrm{gGAE} / 100 \mathrm{~g}$, while its antioxidant activity and tyrosinase enzyme had an $\mathrm{IC}_{50}$ value of $4.02 \mu \mathrm{g} / \mathrm{mL}$ and $580.19 \mu \mathrm{g} / \mathrm{mL}$, respectively. Based on physical stability, it remained stable after 28-day storage with an antioxidant and tyrosinase enzyme inhibitory with $\mathrm{IC}_{50}$ values $19.88 \mu \mathrm{g} / \mathrm{mL}$ and $702.26 \mu \mathrm{g} / \mathrm{mL}$, respectively. In conclusion, this study showed that the serum gel dosage form of GCB extract could be used to face lightening products.
\end{abstract}

Keywords: Coffea robusta L, Serum Gel Dosage Form, Antioxidant, Tyrosinase Enzyme.

(C) RASĀYAN. All rights reserved

\section{INTRODUCTION}

Free radicals could directly damage various cellular structural membranes, proteins, DNA, and lipids on the skin. Its production increases along with age, while the mechanisms of endogenous defense decrease. ${ }^{1,2}$ This imbalance leads to progressive damage of cellular structures, thereby accelerating the aging process. The use of antioxidants, which are substances that protects the body from oxidative stresses by scavenging free radicals, tends to ameliorate these oxidative changes. ${ }^{3}$

During skin aging, the tensile strength is lost, and this leads to wrinkles, roughness, and dryness. ${ }^{4-5}$ Furthermore, it leads to the occurrence of pigment abnormalities such as hyperpigmentation, which occurs due to overproduction and accumulation of melanin. ${ }^{6}$ Tyrosinase enzyme is the key factor in the production of skin pigmentation. Thus, tyrosine inhibitors play an important role to prevent the overproduction and accumulation of melanin. ${ }^{7}$

There are many available synthetics and natural topical products that act as an antioxidant and tyrosinase enzyme in preventing skin aging ${ }^{6,8}$ However, synthetic preparations cause harmful side effects in high doses, therefore, the use of natural sources as an alternative raw material is preferred. ${ }^{9}$ One of the natural sources used as an antioxidant agent and tyrosinase enzyme inhibitor is green coffee bean (Coffea robusta L). It contains caffeine, caffeic acid, chlorogenic acid, and trigonelline, which are great sources of

Rasayan J. Chem., 13(4), 2346-2351(2020)

http://dx.doi.org/10.31788/ RJC.2020.1345866 
RASĀYAN J. Chem.

Vol. 13 | No. 4 |2346-2351| October - December | 2020

antioxidants..$^{10}$ The caffeine and chlorogenic acid could reduce oxidative stress and protect the antioxidant system, especially the green coffee bean. Chlorogenic acids are one of the abundant polyphenols of green coffee beans, which is also a potential source of the antioxidant. ${ }^{11}$ Although previous studies have been carried out on the antioxidant activity of green coffee bean, however, its evaluation in serum gel has not been reported. Serum gel dosage form was a convenient preparation and the most developed cosmetics in the last ten years. ${ }^{12,13}$ Therefore, this study aims to formulate and evaluate the serum gel of green coffee bean (GCB) extract, which acts as an antioxidant and tyrosinase enzyme inhibitor. Gel-based is used in this study due to a high water content which can moisturize and enhance its effects of the main compound in the epithelium. ${ }^{12}$

\section{EXPERIMENTAL}

\section{Plant Material}

The GCB was collected from Arjasari, Bandung, West Java, Indonesia, and authenticated by the School of Life Sciences and Technology, Bandung Institute of Technology with No. 700/I1.CO2.2/PL/2019.

\section{Chemicals}

The chemicals utilized, namely 1,1-diphenyl-2-picrylhydrazyl (DPPH), L-Tyrosine, tyrosinase enzyme, vitamin C, quercetin, gallic acid were purchased from Sigma Aldrich (MO, USA), and kojic acid dipalmitate (Thornhill) was used as a reference.

\section{Extraction Process}

The maceration method was used to extract the GCB using $96 \%$ ethanol for 72 hours at room temperature. Also, the rotary evaporator was used to remove the ethanol solvent at $30-40{ }^{\circ} \mathrm{C}$ to obtain the crude extract.

\section{Phytochemical Screening of the Extract}

Phytochemical screening of extract was conducted to determine the presence of secondary metabolites in GCB extract, including flavonoids and polyphenols.

\section{Determination of Total Phenols}

The GCB extracts were determined for total phenols using the Folin-Ciocalteu assay ${ }^{14}$. A total of $0.5 \mathrm{~mL}$ GCB extract was dissolved in methanol (1000 ppm) and mixed with $5 \mathrm{~mL}$ Folin-Ciocalteu reagent diluted with distilled water at a ratio of $1: 10$ and $4 \mathrm{~mL} \mathrm{Na}_{2} \mathrm{CO}_{3}(1 \mathrm{M})$. This was followed by its incubation for 15 minutes, with the absorbance determined at $765 \mathrm{~nm}$ using a spectrophotometer. The concentration of total phenol was calculated as gallic acid equivalent (GAE), which is a common reference compound. ${ }^{15}$

\section{Antioxidant Activity Test of GCB Extract}

The antioxidant activity of GCB extract was conducted by using the DPPH assay, which was initially used to evaluate the ability of several free radical scavenger molecules. Subsequently, the sample solution was prepared by various concentrations, and mixed with DPPH solution in a ratio of $1: 1$. Furthermore, the absorbance was measured at $515 \mathrm{~nm}$ and calculated to obtain the inhibition percentage value using the following equation:

$$
\text { Inhibition }(\%)=\left[1-\left(\mathrm{A}_{\text {sample }} / \mathrm{A}_{\mathrm{DPPH}}\right)\right] \mathrm{x} 100
$$

Where, \% Inhibition is the percentage capacity of free radical inhibition, and $A_{D P P H}$ is the absorbance of $\mathrm{DPPH}$ solution at $515 \mathrm{~nm}$. Also, the linear regression curve between \% inhibition and sample concentration $\left(\mathrm{IC}_{50}\right)$ was obtained. ${ }^{8,16}$

\section{Tyrosinase Enzyme Inhibitory Activity of GCB Extract}

GCB extracts were dissolved in phosphate buffer consisting of $50 \mathrm{mM}, \mathrm{pH} 6.8$, and $1 \%$ dimethyl sulfoxide to achieve extract concentrations of $500 \mu \mathrm{g} / \mathrm{mL}$. Furthermore, $70 \mu \mathrm{L}$ of the extract solution of each dilution was added to $30 \mu \mathrm{L}$ of the tyrosinase enzyme (Sigma, 333 units $/ \mathrm{mL}$ in phosphate buffer), with the plates incubated at ambient temperature for $5 \mathrm{~min}$. Approximately $110 \mu \mathrm{L}$ of the substrate in $1 \mathrm{mM}$ L-tyrosine was incubated at ambient temperature for $30 \mathrm{~min}$, with the solution measured using a microwell plate reader at $492 \mathrm{~nm}$ to determine the $50 \%$ inhibitory $\left(\mathrm{IC}_{50}\right)$ concentration value. The percentage of tyrosinase enzyme activity inhibition was determined as follows:

$$
\text { Inhibition }(\%)=[(A-B) / A] \times 100
$$


RASĀYAN J. Chem.

Vol. 13 | No. 4 |2346-2351| October - December | 2020

Where, $A$ is the absorbance of kojic acid as a reference at $492 \mathrm{~nm}$, and $B$ is the absorbance of green coffee bean extracts at $492 \mathrm{~nm} .{ }^{17}$

\section{Formulation of Serum Gel From GCB Extract}

The GCB extract and kojic acid were formulated into serum gel dosage form according to the formula shown in Table-1. Kojic acid serum gel was made for comparison. Hydroxyethyl cellulose (HEC) was dispersed into distilled water $\left(50^{\circ} \mathrm{C}\right)$ and constantly mixed using a mechanical stirrer till a homogenous solution was obtained. Extract and all ingredients were dissolved in distilled water before being added to the HEC solution. The physical stability of serum gel consisting of GCB extract was evaluated to determine its organoleptic property, homogeneity, $\mathrm{pH}$, viscosity, and spreadability, after 28 -day storage. ${ }^{18}$

\begin{tabular}{c|c}
\multicolumn{2}{c}{ Table-1: Formulation of Serum Gel Containing GCB Extract } \\
\hline Ingredients & Composition of Serum Gel (\%) \\
\hline GCB extract & 0.5 \\
\hline HEC & 0.5 \\
\hline Propylene glycol & 10 \\
\hline DMSO & 2 \\
\hline Methylparaben & 0.3 \\
\hline Coffee essence & q.s \\
\hline Distilled water ad & 100 \\
\hline
\end{tabular}

RESULTS AND DISCUSSION

The GCB extract obtained from ethanol maceration produced a $29.46 \%$ recovery rate, which showed that as a universal solvent, it can extract both polar and non-polar compounds. ${ }^{19}$ The maceration method was used to protect the substances contained in the GCB extract from destabilization due to heating. ${ }^{6}$ Base on phytochemical screening i.e. alkaloids, flavonoids, polyphenol, and quinones was detected in GCB extract. The research showed that the total phenolic content of GCB extract in terms of gallic acid equivalent was $9.51 \mathrm{gGAE} / 100 \mathrm{~g}$. The major phenolic acid contained in GCB extract was chlorogenic acid known as a potent antioxidant compound. ${ }^{20-21}$

\section{The Antioxidant Activity}

The phenolic compounds can donate hydrogen to reduce the stable radical DPPH. This mechanism changes the radical DPPH into the yellow-colored nonradical diphenyl-picrylhydrazine. ${ }^{10}$ The changing colors of DPPH from purple to yellow-colored nonradical diphenyl-picrylhydrazine indicated the scavenging potential of the antioxidant conserve, while the hydrogen donating ability generally attributed to the antioxidant activity of natural plant extract. ${ }^{22-24}$ Free radicals cause auto-oxidation of unsaturated lipids in food. Antioxidants can intercept the free radical chain of oxidation by donating hydrogen from the phenolic hydroxyl groups, thereby forming a stable end product, which does not initiate or propagate oxidation of the lipids. ${ }^{25}$ The result showed that the $\mathrm{IC}_{50}$ values of GCB extract are similar to kojic acid and vitamin $\mathrm{C}$ as references. Table- 2 shows the result of antioxidant GCB extract by DPPH method.

Table-2: The Antioxidant Activity of GCB Extract
\begin{tabular}{c|c}
\hline Sample & $\mathrm{IC}_{50}(\mu \mathrm{g} / \mathrm{mL})$ \\
\hline GCB extract & 4.01 \\
\hline Kojic Acid & 3.97 \\
\hline Vitamin C & 3.82 \\
\hline
\end{tabular}

\section{The Tyrosinase Enzyme Inhibitory Activity}

The tyrosinase enzyme inhibitory activity from GCB extract was determined by measuring the amount of dopachrome from L-tyrosine, as shown in Table-3.

The result showed that the $\mathrm{IC}_{50}$ values of GCB extract are similar to kojic acid and vitamin $\mathrm{C}$ as a positive control. However, base on the IC50 value, the activity was categorized as weak. Despite showing weak activity, the antioxidant compounds contained in green coffee bean extract might promote the tyrosinase inhibition activity due to their antioxidative synergistic. ${ }^{26}$ Tyrosinase is a rate-limiting enzyme obtained when tyrosine is converted to dopaquinone via L-Tyrosine and L-DOPA. Therefore, tyrosine inhibitors 
RASĀYAN J. Chem.

Vol. 13 | No. 4 |2346-2351| October - December | 2020

play an important role to control melanin biosynthesis and prevent the occurrence of hyperpigmentation. ${ }^{7}$ The previous article also reported that coffee bean extract inhibits tyrosinase enzyme due to the components of triglycerides with the ability to whiten products. ${ }^{10}$

Table-3: The Tyrosinase Enzyme Inhibitory Activity From GCB Extract

\begin{tabular}{c|c}
\hline Sample & $\mathrm{IC}_{50}(\mu \mathrm{g} / \mathrm{mL})$ \\
\hline GCB extract & 580.19 \\
\hline Kojic Acid & 573 \\
\hline
\end{tabular}

The serum gel was formulated due to its advantages such as contact time, high water content, and the ability to reduce the inflammation risk. HEC acts as a polymer widely used in the gel formulation due to its efficacy, biosafety, and stability. ${ }^{27}$ Propylene glycol was used as a humectant to prevent the skin from drying, improve solubility, and diffuse the active compounds. ${ }^{12}$ Meanwhile, Methylparaben, which is an anti-fungal, was absorbed through the skin, hydrolyzed to p-hydroxybenzoic acid, and excreted without accumulating in the body. ${ }^{28-29}$ DMSO was also widely used as a permeation enhancer of hydrophilic and hydrophobic drugs in the topical dosage form. Thus, in this study, it was used to increase the solubility and permeability of the hydrophobic and hydrophilic compounds contained in the extract. ${ }^{30}$

The serum gel formulation has a homogeneous, smooth texture, and characteristic of GCB extract. The homogeneity of serum gel characteristics did not change significantly after 28 days of storage. The $\mathrm{pH}$ of serum gel consisting of GCB extract is shown in Fig.-1.

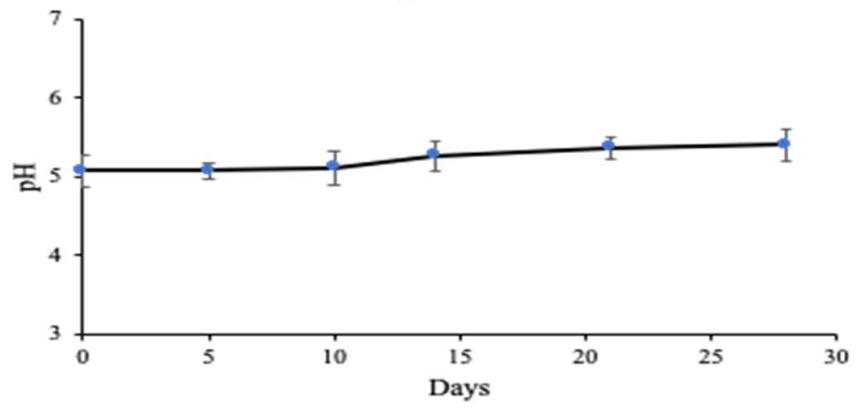

Fig.-1: $\mathrm{pH}$ of Serum Gel Consisting of GCB Extract (The results were measured as mean \pm SD; $\mathrm{n}=3$ )

The result showed that the $\mathrm{pH}$ of serum gel remained similar after 28 days of storage for topical preparations, which is between $4.5-6.5 .^{6}$ The viscosity of serum gel consisting of GCB extract is shown in Fig.-2.

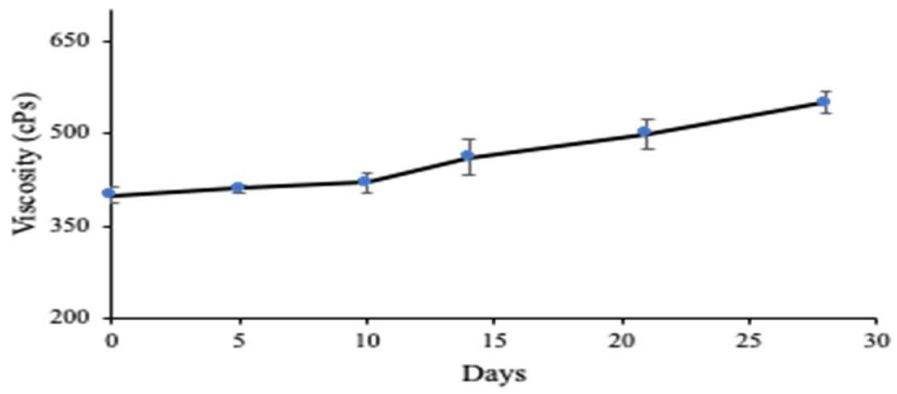

Fig.-2: Viscosity of Serum Gel Consisting of GCB Extract (The results were measured as mean \pm SD; $n=3$ )

The result showed that the viscosity of serum gel consisting of GCB extract remained similar after 28 days at 230-1150 cPs. Spreadability is the ability of the sample to spread on the skin. Therefore, it is one of the important evaluations in serum gel preparations due to its ability to affect the efficacy of the drug, ${ }^{31-32}$ as shown in Fig.-3.

The result showed that the spreadability of serum gel consisting of GCB extract remained similar after 28 days of storage and acceptable between $5-7 \mathrm{~cm} .{ }^{16}$ Spreadability is inversely related to the polymer concentration, which can increase the repulsion between chains. ${ }^{33}$ The result of antioxidant activity and tyrosinase enzyme inhibitory activity of serum gel consisting of GCB extract are shown in Table- 4 . 
RASĀYAN J. Chem.

Vol. 13 | No. 4 |2346-2351| October - December | 2020

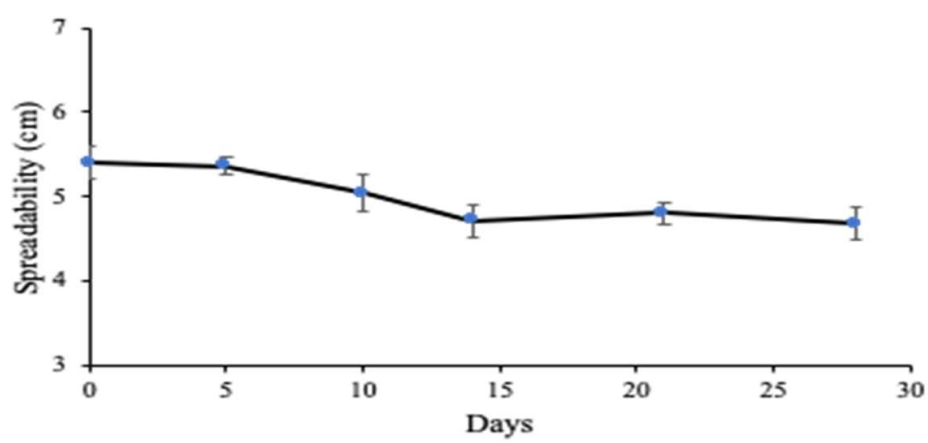

Fig.-3: The Spreadability of Serum Gel Consisting of GCB Extract (The results were measured as mean \pm SD; $n=3$ )

Table-4: The Antioxidant Activity and Tyrosinase Enzyme Inhibitory Activity of Serum Gel

\begin{tabular}{l|c|c}
\multicolumn{1}{c|}{ Sample } & $\begin{array}{c}\mathrm{IC}_{50} \text { of Antioxidant Activity } \\
(\mu \mathrm{g} / \mathrm{ml})\end{array}$ & $\begin{array}{c}\mathrm{IC}_{50} \text { of Tyrosinase Enzyme Inhibitory } \\
\text { Activity }(\mu \mathrm{g} / \mathrm{ml})\end{array}$ \\
\hline Serum gel containing GCB extract & 19.88 & 702.26 \\
\hline Serum gel containing Kojic Acid & 12.20 & 640.37 \\
\hline
\end{tabular}

The serum gel of GCB extract showed antioxidant activity and tyrosinase enzyme inhibition at $\mathrm{IC}_{50}$ values of $19.88 \mu \mathrm{g} / \mathrm{ml}$ and $702.26 \mu \mathrm{g} / \mathrm{ml}$, respectively. This result is similar to the serum gel of kojic acid as a reference with an $\mathrm{IC}_{50}$ value of $12.20 \mu \mathrm{g} / \mathrm{ml}$ and $640.37 \mu \mathrm{g} / \mathrm{ml}$ for antioxidant and tyrosinase enzyme inhibitory activity. The serum gel of GCB extract, which contains phenolic compounds, should penetrate the epidermis of the skin. Thus, it might prevent the oxidation process of tyrosine to dopaquinone and reduce the risk of hyperpigmentation..$^{10,24,34,35}$

\section{CONCLUSION}

In this research, the phenolic compounds in GCB extract could prevent the oxidation process and promote the tyrosinase inhibition due to their antioxidative synergistic. These activities were confirmed by similar $\mathrm{IC}_{50}$ values of kojic acid and vitamin $\mathrm{C}$ as references. Based on the physical stability, including organoleptic property, homogeneity, $\mathrm{pH}$, viscosity, and spreadability, the serum gel of GCB extract was stable after 28day storage with antioxidant and tyrosinase enzyme inhibitory $\mathrm{IC}_{50}$ values of $19.88 \mu \mathrm{g} / \mathrm{mL}$ and 702.26 $\mu \mathrm{g} / \mathrm{mL}$, respectively. This study demonstrated that the serum gel dosage form of GCB extract could be used to face lightening products.

\section{REFERENCES}

1. G, Singh, N. Kaur, Rasayan Journal of Chemistry, 12(4), 2267(2019), DOI: 10.31788/RJC.2019.1245489

2. S. Briganti, M. Picardo, Journal of the European Academy of Dermatology and Venereology, 17(6), 663(2003), DOI:10.1046/j.1468-3083.2003.00751.x

3. V. Lobo, A. Patil, A. Phatak, N. Chandra, Pharmacognosy Reviews, 4(8), 118(2010), DOI: $10.4103 / 0973-7847.70902$

4. T. Quan, Z. Qin, W. Xia, Y. Shao, J.J. Voorhees, G.J. Fisher, In Journal of Investigative Dermatology Symposium Proceedings, 14(1), 20(2009), DOI:10.1038/jidsymp.2009.8

5. G.E. Costin, V.J. Hearing, The FASEB journal, 21(4), 976(2007), DOI:10.1096/fj.06-6649rev

6. A. Budiman, M.R. Zelika, K.Y. Nadiatul, D.L. Aulifa, International Journal of Drug Delivery Technology, 9(4), 525(2019), DOI:10.25258/ijddt.9.4.3

7. P. Limtrakul, S. Yodkeeree, P. Thippraphan, W. Punfa, J. Srisomboon, BMC Complementary and Alternative Medicine, 16(1), 497(2016), DOI:10.1186/s12906-016-1484-3

8. A. Budiman, A. Praditasari, D. Rahayu, D.L. Aulifa, Journal of Pharmacy \& Bioallied Sciences, 11(3), 216(2019), DOI:10.4103/jpbs.JPBS_57_18

9. I. Willis, A. Kligman, J. Epstein, Journal of Investigative Dermatology, 59(6), 416(1972), DOI: 10.1111/1523-1747.ep12627594

10. K. Kiattisin, T. Nantarat, P. Leelapornpisid, Academic Journals, 8(10), 182(2016), DOI: 10.5897/JPP2016.0413 
RASĀYAN J. Chem.

Vol. 13 | No. 4 |2346-2351| October - December | 2020

11. M. Jeszka-Skowron, A. Sentkowska, K. Pyrzyńska, M.P. De Peña, European Food Research and Technology, 242(8), 1403(2016), DOI:10.1007/s00217-016-2643-y

12. S. Surini, H. Mubarak, D. Ramadon. Journal of Young Pharmacists, 10(2), s51(2018), DOI: 10.5530/jyp.2018.2s.10

13. W. Zhu, J. Gao, Journal of Investigative Dermatology Symposium Proceedings, 13(1), 20(2008), DOI: $10.1038 /$ jidsymp.2008.8

14. Sumaiyah, Masfria, A. Dalimunthe, Rasayan Journal of Chemistry, 11(2), 505(2018), DOI: 10.31788/RJC.2018.1122068

15. S. McDonald, P.D. Prenzler, M. Antolovich, K. Robards, Food chemistry, 73(1), 73(2001), DOI: 10.1016/S0308-8146(00)00288-0

16. O. Atolani,C.B. Adeosu, A.P. Oluyori, J. Olota, Rasayan Journal of Chemistry, 12(3), 1052(2019), DOI: $10.31788 /$ RJC.2019.1235122

17. A. Adhikari, H.P. Devkota, A. Takano, K. Masuda, T. Nakane, P. Basnet, et al., International Journal of Cosmetic Science, 30(5), 353(2008), DOI:10.1111/j.1468-2494.2008.00463.x

18. A. Budiman, D.L. Aulifa, A.S.W. Kusuma, I.S. Kurniawan, A. Sulastri, National Journal of Physiology, Pharmacy and Pharmacology, 7(9), 987(2017), DOI: 10.5455/njppp.2017.7.0413123052017

19. E.A.S. Shaalan, D. Canyon, M.W.F. Younes, H. Abdel-Wahab, A.H. Mansour, Environment International, 31(8), 1149(2005), DOI:10.1016/j.envint.2005.03.003

20. M.M. de Freitas, P.R. Fontes, P.M. Souza, C.W. Fagg, E.N. Guerra, Y.K. de Medeiros Nóbrega, PloS One, 11(9), e0163130 (2016), DOI:10.1371/journal.pone.0163130

21. Q. Jin, J. Yang, L. Ma, J. Cai, J. Li, J, Journal of Food Science, 80(11), C2440(2015), DOI: 10.1111/1750-3841.13099

22. M.M. Naidu, G. Sulochanamma, S.R. Sampathu, P. Srinivas, Food Chemistry, 107(1), 377(2008), DOI: 10.1016/j.foodchem.2007.08.056

23. I. Fidrianny, H. Suhendy, M. Insanu, Asian Pacific Journal of Tropical Biomedicine, 8(1), 25(2018), DOI: $10.4103 / 2221-1691.221131$

24. S.M. Klein, G. Cohen, A.I. Cederbaum, Biochemistry, 20(21), 6006(1981), DOI:10.1021/bi00524a013

25. J.M. Lü, P.H. Lin, Q. Yao, C. Chen, Journal of Cellular and Molecular Medicine, 14(4), 840(2010), DOI:10.1111/j.1582-4934.2009.00897.x

26. T.S. Chang, International Journal of Molecular Sciences, 10(6), 2440(2009), DOI:10.3390/ijms10062440

27. L. Li, Y. Ben, S. Yuan, S. Jiang, J. Xu, X. Zhang, PloS One, 7(5), e37381(2012), DOI:10.1371/journal.pone.0037381

28. P.M. Patil, S.B. Wankhede, P.D. Chaudhari, Journal of Pharmacy Research, 6(9), 945(2013), DOI: $10.1016 /$ j.jopr.2013.09.004

29. M.G. Soni, S.L. Taylor, N.A. Greenberg, G.A. Burdock, Food and Chemical Toxicology, 40(10), 1335(2002), DOI:10.1016/S0278-6915(02)00107-2

30. S. Dey, B. Mazumder, J.R. Patel, International Journal of Pharmaceutical Sciences and Drug Research, 1(1), 13(2009), DOI:10.25004/IJPSDR.2009.010104

31. M. Shukr, G.F. Metwally, Tropical Journal of Pharmaceutical Research, 12(6), 877(2013), DOI: $10.4314 /$ tjpr.v12i6.3

32. S.L. Prabu, S. Arun, S. Annie, K. Aravind, Journal of Pharmaceutical Research, 8(2), 89(2009), DOI: $10.18579 /$ jpcrkc/2009/8/2/79771

33. M.D. Contreras, R. Sanchez, International Journal of Pharmaceutics, 234(1-2), 149(2002), DOI: 10.1016/S0378-5173(01)00954-1

34. C. Couteau, L. Coiffard, Cosmetics, 3(3), 27(2016), DOI:10.3390/cosmetics3030027

35. S. Zolghadri, A. Bahrami, M.T. Hassan Khan, J. Munoz-Munoz, F. Garcia-Molina, F. Garcia-Canovas, et al., Journal of Enzyme Inhibition and Medicinal Chemistry, 34(1), 279(2019), DOI: $10.1080 / 14756366.2018 .1545767$

[RJC-5866/2020]

FORMULATION OF THE SERUM GEL 